\title{
PTPN21 wt Allele
}

National Cancer Institute

\section{Source}

National Cancer Institute. PTPN21 wt Allele. NCI Thesaurus. Code C126459.

Human PTPN21 wild-type allele is located in the vicinity of $14 \mathrm{q} 31.3$ and is approximately $89 \mathrm{~kb}$ in length. This allele, which encodes tyrosine-protein phosphatase non-receptor type 21 protein, is involved in protein dephosphorylation. 